\title{
Growth, seed cotton yield and yield attributes of American cotton (Gossypium hirsutum L.) hybrids under different spacing and nitrogen levels
}

\author{
KULVIR SINGH \\ Regional Research Station (P.A.U.), FARIDKOT (PUNJAB) INDIA(Email : kulvir@ pau.edu)
}

\begin{abstract}
Field studies were conducted at Punjab Agricultural University, Regional Station, Faridkot during Kharif 2013 to evaluate the performance of two hirsutum hybrids (FHH200 and LHH144) in main, two spacing levels $(67.5 \times 75 \mathrm{~cm}$ and $67.5 \times 90 \mathrm{~cm})$ in sub and three nitrogen levels (i.e. 112,150 and $187 \mathrm{~kg} \mathrm{~N} / \mathrm{ha}$ ) in sub plots of Split Plot Design replicated thrice. FHH200 recorded significantly highest seed cotton yield (SCY) of $2953.1 \mathrm{~kg} / \mathrm{ha}$ followed by LHH144 (2495.2 kg/ha), while among spacing levels differences were non-significant. Among tested N levels, $150 \mathrm{~kg} \mathrm{~N}$ resulted in highest SCY (2868.1 kg/ha) followed by $187 \mathrm{~kg} \mathrm{~N}(2738.1 \mathrm{~kg} / \mathrm{ha})$ while statistically least SCY was recorded with $112 \mathrm{~kg} \mathrm{~N}(2566.3 \mathrm{~kg} / \mathrm{ha})$. Though cost of cultivation increased with each increase of nutrient levels, but gross as well as net returns improved significantly only up to 100 per cent RD and declined thereafter. B:C ratio was significantly higher under $150 \mathrm{~kg} \mathrm{~N} / \mathrm{ha}(2.34)$ as compared to $187 \mathrm{kgN} / \mathrm{ha}$ (2.15). Farmers should opt for FHH200 and a spacing level of $67.5 \times 75 \mathrm{~cm}$ for hirsutum hybrids and must apply N @ $150 \mathrm{~kg} / \mathrm{ha}$ to realize higher SCY and consequently remunerative returns.
\end{abstract}

Key Words : Fertilizer use efficiency (FUE), Nitrogen levels, Seed cotton yield (SCY), Water productivity (WP)

View Point Article : Singh, Kulvir (2015). Growth, seed cotton yield and yield attributes of American cotton (Gossypium hirsutum L.) hybrids under different spacing and nitrogen levels. Internat. J. agric. Sci., 11 (1): 89-92.

Article History : Received : 21.06.2014; Revised : 13.11.2014; Accepted : 30.11 .2014 